\title{
MARITAL STATUS OF CITIZENS AND FLOODS: CITIZEN PREPAREDNESS FOR RESPONSE TO NATURAL DISASTERS
}

Vladimir M. Cvetković Academy of Criminalistic and Police Studies, Belgrade

This paper presents the results of quantitative research into the influence of marital status on citizen preparedness for response to natural disaster caused by flood in the Republic of Serbia. The aim of such research is a scientific explanation of relationship between marital status and preparedness. In order to realize research, nineteen communities were randomly selected in which 2,500 persons were surveyed, in 2015. On that occasion, households were questioned using the multi-stage random sample. The research results suggest that married would in the highest percentage give money to help flood victims, long-lasting rains make them to think about preparedness for floods, they know what flood is, they are familiar with viruses and infections that accompany the period during and after the flood, they know where in local community elders, disabled and infants live, they know safety procedures for responding during floods, they would evacuate to a friend's place. On the other side, divorced citizens in the lowest percentage take preventive measures to reduce tangible consequences caused by floods, they are not yet prepared, but will start preparing next month, they know what flood is, they would evacuate to the upper floors of the house, say that someone at primary/secondary school and within family educated them on floods, they know what to do after an official warning about approach of flood, they got information about floods at faculty, through informal education and through media. The research results can be used in designing strategies and campaigns aimed to raise the level of preparedness of citizens with regard to their marital status.

Key words: security, natural disaster, flood, citizens, marital status, preparedness, Serbia

\section{Introduction}

nalyses of geospatial and temporal distributions of natural disasters indicate an increase in the number and severity of flood consequences (Cvetković, 2014; Cvetković \& Dragicević, 2014; Cvetković, Gačić, \& Jakovljević, 2015a, 2015b; Cvetković,

*Vladimir M. Cvetković, Ph.D, vladimir.cvetkovic@kpa.edu.rs 
Milojković, \& Stojković, 2014; Devlin, Waterhouse, Taylor, \& Brodie, 2001; Dragićević et al., 2013; Guan, Zheng, Zhang, \& Qin, 2015; Martinez \& Le Toan, 2007; Türkeş \& Sümer, 2004). In domestic and foreign scientific literature, there are various definitions of flood. Flood as a natural disaster is usually defined as the occurrence of unusually large amount of water at a certain place due to the effects of natural forces or artificial causes (dams failure, war, etc.) (Stojanović, 1984: 95); the phenomenon of high water spills from riverbed where high water is the highest reached level of water in the river during a flood (Dragićević \& Filipović, 2009: 193); type of natural disaster that occurs due to spills of high water from natural and artificial recipients, i.e. riverbed and water reservoirs (Milojković \& Mlađan, 2010: 173); result of the overflow of water out of natural and artificial boundaries, that is, when water flow exceeds the capacity of natural and artificial boundaries, that is, when water flow exceeds the capacity of the natural retention or infiltration (Đarmati \& Aleksić, 2004: 117); in water management and hydrotechnical practice the term flood (high water) means the status of water regime when the water level, that is, the river flow increases causing discharge of water from the riverbed and flooding coastal terrain (Prohaska, llic, Miloradović, \& Petković, 2009, p. 191); result of spillover beyond the river embankments and spreading across nearby valley (Marlene \& Carmichael, 2007:45); result of raising of water level above natural or artificial dams (embankments) which by its expansion endangers lives and property of people (Smith \& Petley, 2009, p. 239); flood as a natural disaster can involve raising of water level above the boundaries of its coasts accompanied by uncontrolled expansion of water in accordance with characteristics of terrain, causing consequences to people, the environment and their property (Cvetković, 2015: 63).

In the theory of disasters, great attention is paid to research into preparedness of citizens for response to various natural disasters (Momani \& Salmi, 2012; Ronan, Alisic, Towers, Johnson, \& Johnston, 2015; Tomio, Sato, Matsuda, Koga, \& Mizumura, 2014; Uscher-Pines, Chandra, \& Acosta, 2013; Cvetković, 2015a, 2015b, 2015c, 2016b; Cvetković, Gačić, \& Jakovljević, 2015). Gillespie et al. (Gillespie, Colignon, Banerjee, Murty, \& Rogge, 1993: 36) define preparedness as measures undertaken before the disaster in order to improve response and recovery from the resulting consequences. Thus, the authors integrate measures of planning, procedural training and procurement of inventories. International Organization of the Red Cross considers preparedness as any measures taken aimed at anticipation and possible prevention, mitigation of consequences of disaster on vulnerable populations and efficient response that is dealing with resulting consequences (Societies, 2000, p. 6). Terney et al (Tierney, Lindell, \& Perry, 2002, p. 27) suggest that preparedness involves activities undertaken to strengthen capabilities and opportunities of social groups to respond to situations caused by disasters. Thereby, they emphasize the inconsistency of preparedness with a clear focus on its two objectives: 1. to help people to avoid the threat (Cvetković, 2016a; Cvetković \& Gačić, 2016; Štrbac \& Terzić, 2007); 2. to develop capacities and mechanisms with the aim of an effective response to disasters. Authors also focused on examination of correlation between marital status and preparedness to respond (Russell, Goltz, \& Bourque, 1995; Spittal, McClure, Siegert, \& Walkey, 2008). Tomio et al suggest that older, female and better educated individuals are positively associated with a higher level of disaster preparedness at the household level, while at the community level such correlation exists with length of residence, marital status, presence of an older family member (Tomio et al., 2014). 
For these reasons, the paper that represents the quantitative research examines the influence of marital status on preparedness of citizens to respond to a natural disaster caused by floods in the Republic of Serbia. The research results can be used for the adoption of strategy to improve preparedness of citizens for response.

\section{Methodology and data}

\section{Study area}

For realization of the study some communities were selected with high and low risk of onset of lowland and flash flooding. The survey was conducted on the territory of a large number of local communities with different demographic and social characteristics to be generalized to the whole population in Serbia. The urban and rural communities in different parts of Serbia were selected. Specifically, the study was conducted in the following communities: Obrenovac, Šabac, Kruševac, Kragujevac, Sremska Mitrovica, Priboj, Batočina, Svilajnac, Lapovo, Paraćin, Smederevska Palanka, Jaša Tomić, Loznica, Bajina Bašta, Smederevo, Novi Sad, Kraljevo, Rekovac and Užice.

\section{Study design with variables}

Operationalization of the theoretical notion of preparedness to respond has given three dimensions that have been studied by identification of larger number of variables for each one. Perception of preparedness includes variables on preparedness at different levels; barriers for raising the level of preparedness; variables on the expectation on help from different categories of people and organizations; assessment of effectiveness of first responders to respond. Knowledge through variables related to the level of knowledge was examined; flood risk map; knowing where they are and how to use them, willingness to train, willingness for methods of education, way to obtain the information about floods. And the third dimensions, supplies relate to having oral/written plans, having supplies of food and water, a transistor radio, flashlight, hoe, shovel, hoe and spade, first aid kit, insurance.

\section{Sample}

The population consists of all adult residents of local communities in which there is a risk to occur flash flood or flood caused by dam failure. The sample size has been adjusted with the geographical (local communities from all regions of Serbia will be represented) and demographic size of the communities themselves. It was randomly selected sample of 19 out of 150 municipalities and 23 towns and the city of Belgrade (Table 1). The research was undertaken in those areas that were most affected related to the amount of water or potential risk. In the survey, questioning strategy was applied to households with the use of a multi-stage random sample. In the first step, which refers to the primary causal units, parts of community in the research were selected. This process was accompanied by creation of map and determination of percentage share of each such segment in the total sample. In the second stage, streets or sections of streets were determined on the level of primary causal units. Each 
research core was determined as the path with specified start and end points of movement. In the next step, households in which the survey would be conducted were defined. The number of households is harmonized with population count of community. The final step referred to selection of respondents within households previously defined. The selection of respondents was conducted following the procedure of next birthday for adult members of household. The process of interviewing for each local authority was held three days in a week (including weekends) at different times of days. The study surveyed with 2.500 persons.

Table 1 - The number of the respondents in local communities in the study

\begin{tabular}{|c|c|c|c|c|c|c|}
\hline 胥 & 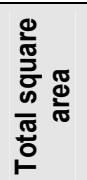 & 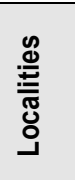 & $\begin{array}{l}\frac{}{0} \\
\frac{0}{\pi} \\
\frac{\pi}{3} \\
\frac{0}{0}\end{array}$ & 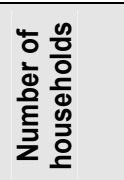 & 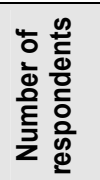 & 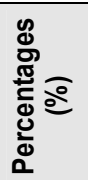 \\
\hline Obrenovac & 410 & 29 & 72682 & 7752 & 178 & 7.12 \\
\hline Šabac & 797 & 52 & 114548 & 19585 & 140 & 5.60 \\
\hline Kruševac & 854 & 101 & 131368 & 19342 & 180 & 7.20 \\
\hline Kregujevac & 835 & 5 & 179417 & 49969 & 191 & 7.64 \\
\hline Sremska Mitrovica & 762 & 26 & 78776 & 14213 & 174 & 6.96 \\
\hline Priboj & 553 & 33 & 26386 & 6199 & 122 & 4.88 \\
\hline Batočina & 136 & 11 & 11525 & 1678 & 80 & 3.20 \\
\hline Svilajnac & 336 & 22 & 22940 & 3141 & 115 & 4.60 \\
\hline Lapovo & 55 & 2 & 7650 & 2300 & 39 & 1.56 \\
\hline Paraćin & 542 & 35 & 53327 & 8565 & 147 & 5.88 \\
\hline Smederevska Palanka & 421 & 18 & 49185 & 8700 & 205 & 8.20 \\
\hline Sečanj - Jaša Tomić & 82 & 1 & 2373 & 1111 & 97 & 3.88 \\
\hline Loznica & 612 & 54 & 78136 & 6666 & 149 & 5.96 \\
\hline Bajina Bašta & 673 & 36 & 7432 & 3014 & 50 & 2.00 \\
\hline Smederevo & 484 & 28 & 107048 & 20948 & 145 & 5.80 \\
\hline Novi Sad & 699 & 16 & 346163 & 72513 & 150 & 6.00 \\
\hline Kraljevo & 1530 & 92 & 123724 & 19360 & 141 & 5.64 \\
\hline Rekovac & 336 & 32 & 10525 & 710 & 50 & 2.00 \\
\hline Užice & 667 & 41 & 76886 & 17836 & 147 & 5.88 \\
\hline Total: 19 & 10784 & 634 & 1500091 & 283602 & 2500 & 100 \\
\hline
\end{tabular}

According to Statistical Office of Serbia, women have a share of $51.3 \%$ and men $48.7 \%$ in overall population. Observed in absolute numbers, of total 7,498,001 inhabitants, in Serbia live 3,852,071 women and 3,645,930 men. Similar as in the entire population, the sample has more women $(50.2 \%)$ than men $(49.8 \%)$. In 2014 , the average age of respondents was 39.95 (men 40.9 and women 38.61). Observing the educational structure of citizens who are included in the survey sample, it also can be noted that majority of population $(41.3 \%)$ has secondary/four years school. The smallest percentage of 
population has completed master $(2.9 \%)$ and doctoral studies $(0.4 \%)$. Marital status can be viewed from the aspect of legal marital status and factual marital status which also includes persons living in extramarital community. In the sample, married people account to $54.6 \%$, widow/widower $3 \%$, unmarried (single) $18.8 \%$, engaged $2.7 \%$ and in relationship $16.9 \%$. Table 2 gives a detailed overview of sample structure of surveyed citizens.

Table 2 - Sample structure of interviewed citizens

\begin{tabular}{|c|c|c|c|}
\hline Variables & Categories & Frequency & $\begin{array}{c}\text { Percentages } \\
(\%)\end{array}$ \\
\hline \multirow{2}{*}{ Gender } & Male & 1244 & 49.8 \\
\hline & Female & 1256 & 50.2 \\
\hline \multirow{6}{*}{ Age } & $18-28$ & 711 & 28.4 \\
\hline & $28-38$ & 554 & 22.2 \\
\hline & $38-48$ & 521 & 20.8 \\
\hline & $48-58$ & 492 & 19.7 \\
\hline & $58-68$ & 169 & 6.8 \\
\hline & Over 68 & 53 & 2.2 \\
\hline \multirow{7}{*}{ Education } & Primary & 180 & 7.2 \\
\hline & Secondary/3 years & 520 & 20.8 \\
\hline & Secondary/4 years & 1032 & 41.3 \\
\hline & Higher & 245 & 9.8 \\
\hline & High & 439 & 17.6 \\
\hline & Master & 73 & 2.9 \\
\hline & Doctorate & 11 & 0.4 \\
\hline \multirow{6}{*}{ Marital status } & Single & 470 & 18.8 \\
\hline & In relationship & 423 & 16.9 \\
\hline & Engaged & 67 & 2.7 \\
\hline & Married & 1366 & 54.6 \\
\hline & Divorced & 99 & 4.0 \\
\hline & Widow / widower & 75 & 3.0 \\
\hline \multirow{4}{*}{$\begin{array}{l}\text { Distance between household } \\
\text { and river }(\mathrm{km})\end{array}$} & Up to $2 \mathrm{~km}$ & 1479 & 59.2 \\
\hline & From 2 to 5 & 744 & 29.8 \\
\hline & From 5 to 10 & 231 & 9.2 \\
\hline & Over 10 & 46 & 1.8 \\
\hline \multirow{4}{*}{ Number of household members } & Up to 2 & 63 & 2.5 \\
\hline & From 2 to 4 & 1223 & 48.9 \\
\hline & From 4 to 6 & 639 & 25.6 \\
\hline & Over 6 & 575 & 23.0 \\
\hline \multirow{2}{*}{ Employment status } & Yes & 1519 & 60.8 \\
\hline & No & 883 & 35.3 \\
\hline \multirow{5}{*}{ Size of apartment / house $\left(\mathrm{m}^{2}\right)$} & Up to 35 & 128 & 3.9 \\
\hline & $35-60$ & 237 & 7.2 \\
\hline & $60-80$ & 279 & 8.5 \\
\hline & $80-100$ & 126 & 3.9 \\
\hline & Over 100 & 45 & 1.4 \\
\hline \multirow{4}{*}{ Income level - monthly } & Up to 25,000 RSD & 727 & 29.1 \\
\hline & Up to 50,000 RSD & 935 & 37.4 \\
\hline & $\mathrm{U}$ to $75,000 \mathrm{RSD}$ & 475 & 19.0 \\
\hline & Over 90,0000 RSD & 191 & 7.6 \\
\hline
\end{tabular}

* 1 US Dollar $=111$ RSD 


\section{Instrument}

For validity and reliability studies of the data gathering instrument five steps were taken. In the first step, we determined some scales used for measuring the preparedness of citizens to respond to disasters in general or to specific natural disaster. The third step included the aforementioned operationalization of preparedness for response and deciding on the three basic dimensions (perception of preparedness to respond, knowledge and supplies). In the fourth step, we defined variables for each dimension (perceptions of preparedness to respond - 46 variables; knowledge - 50 and supplies - 18), then for each variable it was taken, adapted or specially designed question in instrument. The fifth and final step was carried out preliminary (pilot) study in Batočina with the aim of checking constructed instrument (its internal compliance of the scale, i.e. degree of relatedness of items of which it is composed, and whether instructions, questions and values on scale are clear).

\section{Data analysis}

Statistical analysis of collected data was performed by IBM's software package SPSS. Chi-square test of independence $\left(x^{2}\right)$ was used for testing of the connection between marital status and categorical variables on perception, knowledge and having supplies and plans for a natural disaster caused by flood. On that occasion additional assumptions were completed about minimum expected frequency in each cell, which amounted to five or more. Assessment of impact level was performed by phi coefficient representing the correlation coefficient ranging from 0 to 1 , where a higher number indicates a stronger relationship between the two variables. Koen criteria were used: from 0.10 for small, 0.30 for medium and 0.50 for large effect (Cohen, 1988). For tables larger than 2 by 2 , to assess the impact level it was used Cramer's $v$ coefficient which takes into account the number of degrees of freedom. Accordingly, for R-1 or K-1 is equal to 1 , we used the following criteria of impact size: small $=0.01$, medium $=0.30$ and large $=0.50$. To test the connection between marital status and continuous dependent variables on the perception, knowledge and having supplies and plans for natural disasters caused by floods, it was selected independent samples t-test and ANOVA. Before proceeding to the implementation of the test, we examined general and specific assumptions for its implementation.

\section{Research results}

The results of Chi-square test of independence $(x 2)$ showed a statistically significant relationship between marital status and the following variables: preventive measures $(p=0.000<0.05, v=0.09$ - small influence); financial resources $(p=0.002<0.05, v=0.08$ small influence); engaged in the field ( $p=0.000<0.05, v=0.12$ - small influence); engaged in a detention center ( $p=0.000<0.05, v=0.12$ - small influence); long-lasting rains ( $p=0.000<0.05, v=0.10$ - small influence); media reports $(p=0.000<0.05, v=0.11$ - small influence); and level of preparedness ( $p=0.000<0.05, v=0.07$ - small influence). On the other hand, there was no statistically significant relationship with variables: visiting to the flooded areas $(p=0.061>0.05)$, and raising of water level $(p=0.170>0.05)$ (Table 1$)$. 
Marital Status of Citizens and Floods: Citizen Preparedness for Response to Natural Disasters

According to the results, in the highest percentage:

- Citizens who live alone would engage to help threatened population in the field $(23.2 \%)$, would engage in detention centers to provide help to flood victims (9.3\%);

- Citizens who are in relationships think about preparedness for floods because of visiting to the flooded areas (13.8\%);

- Citizens who are engaged take preventive measures to reduce tangible consequences of floods $(22.7 \%)$, they are still not prepared, but will start preparing next month $(16.7 \%)$, have recently begun to prepare (9.1\%), have prepared for at least 6 months $(32.4 \%)$;

- Citizens who are married would give money to help flood victims $(32.9 \%)$, longlasting rains make them to think on preparedness (43.9\%);

- Citizens who are divorced are not yet prepared, but intend to get prepared in the next 6 months (23.2\%);

- Citizens who have lost their husband/wife think on preparedness for response to floods due to media reports (55.6\%), do not do anything to prepare themselves (69\%);

On the other hand, in the smallest percentage:

- Citizens who are in relationships would engage in detention centers to provide help to flood victims (2.3\%);

- Citizens who are engaged think about preparedness for floods due to visiting to the flooded areas $(6.1 \%)$, media reports $(21.2 \%)$, do not do anything to prepare themselves (47\%);

- Citizens who are divorced take preventive measures to reduce tangible consequences of floods $(6.4 \%)$ they are still not prepared, but will start preparing next month $(2.4 \%)$, have recently begun to prepare $(1.2 \%)$;

- Citizens who have lost their spouses would give money to help flood victims $(10.6 \%)$ have performed preparation for at least 6 months $(2.8 \%)$;

- Citizens who have lost their spouses would engage to help threatened population in the ground $(0.1 \%)$, think on preparedness for floods due to long-lasting rains $(25.8 \%)$ they are still not prepared, but intend to get prepared in the next 6 months $(9.7 \%)$.

Table 3 - Results of the chi-square test of independence $(x 2)$ between marital status and mentioned variables on the perception of preparedness for response

\begin{tabular}{|c|c|c|c|c|}
\hline & value & $\mathrm{df}$ & Asymp. Sig. (2 - sided) & Cramers v \\
\hline Preventive measures & 39,143 & 10 &, $000^{*}$ & 093 \\
\hline Money & 18,709 & 5 &, $002^{*}$ & 089 \\
\hline Field deployed & 37,901 & 5 &, $000^{*}$ & ,127 \\
\hline Detention center deployed & 37,680 & 5 &, $000^{*}$ & ,126 \\
\hline Visiting to the flooded areas & 11,507 & 5 & 061 & 051 \\
\hline Long-lasting rain periods & 26,992 & 5 &, $000^{*}$ & ,108 \\
\hline Raising of river levels & 7,753 & 5 & 170 & 057 \\
\hline Media reports & 27,814 & 5 &, $000^{*}$ &, 110 \\
\hline Level of preparedness & 57,548 & 25 &, $000^{*}$ & ,071 \\
\hline
\end{tabular}

*statistically significant correlation - $p \leq 0.05$

One-way ANOVA was used for studying the effect of marital status of citizens on the following continuous dependent variables. Subjects were divided according to marital status into 6 groups (single, in a relationship, engaged, married, divorced and widower/widow). Using homogeneity of variance test it was examined equality of variances in the results for each of 
the 6 groups. Bearing in mind the results of Levene Statistic, the assumption of homogeneity of variance is not violated in the following variables: importance of taken measures; first responders; I am not threatened; I have no time for that; I have no support; I can not prevented it; international humanitarian organizations; the police; self-organized individuals; awareness; citizens in flooded areas; efficiency of the emergency service; efficiency of staff for emergency situations. For variable in which the assumption is violated, there is a table ,,Robust Tests of Equality of Means" and the results of two tests, Welsh's (Welsh) and Brown's (Brown Forsythe) tests, resistant to the violation of the assumption of homogeneity of variance.

According to the results, there is a statistically significant difference between the means of those groups in the following continuous dependent variables: individual preparedness $(F=6.19, p=.000$, eta squared $=0.018$ - small influence); household preparedness $(F=4.00, p=0.002$, eta squared $=0.009)$; preparedness of local community $(F=2.49, p=.002$, eta squared $=0.005$ - small influence $)$; personal abilities $(F=11.592, p=.000$, eta squared $=0.031$ - small influence); it is very expensive $(F=2.84$, $p=0.016$, eta squared $=0.005$ - small influence); It will not influence on safety $(F=4.009$, $p=0.002$, eta squared $=0.008$ - small influence); household members $(F=5.48, p=0.000$, eta squared $=0.018$ - small influence); neighbors $(F=11.61, p=0.000$, eta squared $=0.029$ - small influence); $\mathrm{NHO}-(\mathrm{F}=6.46, p=.000$, eta squared $=0.013$ - small influence); first responders $(F=5.22, p=.000$, eta squared $=0.013-$ small influence); emergency service $(F=2.65, p=.023$, eta squared $=0,006$ - small influence); Army $(F=5.28$, $p=0.000$, eta squared $=0.013$ - small influence $)$; interest $(F=7.98, p=.000$, eta squared $=0.019$ - small influence); Help would not mean much $(F=9.024, p=.000$, eta squared $=0.026)$; Others have helped $(F=2.94, p=0.13$, eta squared $=0.006$ - small influence); Job of state authorities ( $F=11.65, p=.000$, eta squared $=0.019$ - small influence); I have no time for that $(F=4.602, p=.000$, eta squared $=0.01$ - small influence); police efficiency $(F=0.278, p=0.001$, eta squared $=0.005)$; efficiency of first responders $(F=3.83, p=0.02$, eta squared $=0.008$ - small influence); efficiency of the army $(F=6.09, p=0.000$, eta squared $=0.016$ - small influence $)$; character before. rate $(F=9.95, p=0.000$, eta squared $=0.019$ - a small effect $) ; \mathrm{I}$ am not affected $(F=7.73$, $p=0.000$, eta squared $=0.015$ - small influence); I have no time for that $(F=3.23, p=.006$, eta squared $=0.006$ - small influence); I have no support $(F=4.15, p=.001$, eta squared $=0.008$ - small influence); I can not prevent it $(F=2.93, p=0.012$, eta squared $=0.006$ small influence); $\mathrm{MHO}(\mathrm{F}=4.27, \mathrm{p}=.001$, eta squared $=0.008$ - small influence); Police $(F=3.26, p=.006$, eta squared $=0.006$ - small influence); self-organized individuals $(F=4.06, p=0.001$, eta squared $=0.008)$; awareness $(F=8.44, p=.000$, eta squared $=0.016$ - small influence); Citizens of flooded areas $(F=3.14, p=.008$, eta squared $=0.006)$; efficiency of emergency medical services $(F=5.73, p=0.000$, eta squared $=0.011$ - small influence); and efficiency of staff for emergency situations $(F=4.52, p=.000$, eta squared $=0.009$ - small influence).

Subsequent comparisons using Tukey HSD shows that the observed mean value of:

- Individual preparedness for response to floods statistically significantly $(p<0.05)$, and mutually differs among citizens who have lost their spouses $(M=2.33, S D=1.44)$ and divorced $(M=2.71, S D=1.36)$, engaged $(M=2.67, S D=1.036)$ and singles $(M=3.07$, $\mathrm{SD}=0.950$ ). Citizens who live alone have the highest level of individual preparedness for response, while the lowest is recorded among citizens who lost their spouses; 
Marital Status of Citizens and Floods: Citizen Preparedness for Response to Natural Disasters

- household preparedness for response to floods statistically significantly $(p<0.05)$, and mutually differs among citizens who have lost their spouses $(M=2.63, S D=1.19)$ and the citizens who live alone $(M=3.14, S D=0.97)$, who are married $(M=3.01, S D=0.95)$, and in a relationship $(M=3.10, S D=0.97)$. Citizens who live alone have the highest level of household preparedness for response, while the lowest is recorded among citizens who lost their spouses;

- preparedness of local community for response to floods statistically significantly $(p<0.05)$, and mutually differs among citizens who have lost their spouses $(M=2.56, S D=1.27)$, and those who are in a relationship $(M=2,97, S D=1.02)$. Citizens who are in a relationship have the highest level of preparedness of local community for response, and the lowest is recorded among citizens who lost their spouses;

- confidence in personal abilities and capabilities to cope with consequences of floods statistically significantly $(p<0.05)$, and mutually differs among citizens who live alone $(M=3.08$, $S D=1.03)$, and who have lost their spouses $(M=1.99, S D=1.21)$. Citizens who live alone have the highest level of confidence in personal abilities and capabilities to deal with consequences, while the lowest is recorded among citizens who lost their spouses;

- importance of taking measures of preparedness statistically significantly $(p<0.05)$, and mutually differs among citizens who have lost their spouses $(M=2.56, S D=1.24)$, and those who live alone $(M=3.32, S D=1.05)$; reason ,I do not consider myself personally or my household at risk" for not taking preventive measures statistically significantly $(p<0.05)$, and mutually differs among citizens who live alone $(M=3.13, S D=1.45)$ and citizens who have lost their spouses $(M=2.41, S D=1.36)$. Citizens who live alone have the highest level of agreement with the stated reason in relation to citizens who have lost their spouses;

- reason ,I have no time for that" for not taking preventive measures statistically significantly $(p<0.05)$, and mutually differs among citizens who are in a relationship $(M=2.87, S D=1.42)$, and citizens who are divorced $(M=2.47, S D=1.11)$. Citizens who are in a relationship have the highest level of agreement with the stated reason in relation to citizens who are divorced;

- reason ,"I think it will not influence on my personal or household safety" for not taking preventive measures statistically significantly $(p<0.05)$, and mutually differs among citizens who are in a relationship $(M=2.97, S D=1.29)$ and citizens who are divorced $(M=2.39, S D=1.39)$. Citizens who are in a relationship have the highest level of agreement with the stated reason in relation to citizens who are divorced;

- reason ,I have no support from the local community” for not taking preventive measures statistically significantly $(p<0.05)$, and mutually differs among citizens who are married $(M=2.67, S D=1.7)$ and citizens who have lost their spouses $(M=3.27$, $\mathrm{SD}=1.42$ ). Citizens who have lost their spouses have the highest level of agreement with the stated reason in relation to citizens who are married;

- reason ,I can not prevent the consequences in any way" for not taking preventive measures statistically significantly $(p<0.05)$, and mutually differs among citizens who have lost their spouses $(M=3.25, S D=1.52)$, and citizens who are divorced $(M=2.53$, $S D=1.40$ ). Citizens who have lost their spouse have the highest level of agreement with the stated reason in relation to citizens who are divorced;

- reliance on family members in the first 72 hours after the occurrence of floods statistically significantly $(p<0.05)$, and mutually differs among citizens who have lost their spouses $(M=4.37, S D=1.21)$ and citizens who are divorced $(M=3.46, S D=1.64)$. Citizens who have lost their spouses have the highest level of reliance on family members in relation to citizens who are divorced who have the lowest level; 
- reliance on neighbors in the first 72 hours after the occurrence of floods statistically significantly $(p<0.05)$, and mutually differs among citizens who live alone $(M=3.74, S D=1.23)$ and citizens who are divorced $(M=261, S D=1.43)$. Citizens who live alone have the highest level of reliance on neighbors in relation to divorced citizens who have the lowest level;

- reliance on non-governmental humanitarian organizations in the first 72 hours after the occurrence of floods statistically significantly $(p<0.05)$, and mutually differs among citizens who have lost their spouses $(M=4.37, S D=1.21)$ and citizens who are divorced $(M=3.46, S D=1.64)$. Citizens who have lost their spouses have the highest level of reliance on non-governmental humanitarian organization in relation to divorced citizens who have the lowest level;

- reliance on international humanitarian organizations in the first 72 hours after the occurrence of floods statistically significantly $(p<0.05)$ and mutually differs for citizens who are in a relationship $(M=2.51, S D=1.19)$ and citizens who are divorced $(M=1.98, S D=1.06)$. Citizens who are in a relationship have the highest level of reliance on international humanitarian organization in relation to divorced citizens divorced who have the lowest level;

- reliance on the police in the first 72 hours after the occurrence of floods statistically significantly $(p<0.05)$, and mutually differs among citizens who live alone $(M=3.42$, $S D=1.29)$ and citizens who are divorced $(M=299, S D=1.37)$. Citizens who live alone have the highest level of reliance on the police in such situations compared to divorced citizens who have the lowest level;

- reliance on first responders in the first 72 hours after the occurrence of floods statistically significant $(p<0.05)$, and mutually differs among citizens who live alone $(M=3.76, S D=1.19)$ and citizens who are divorced $(M=3.01, S D=1.42)$. Citizens who live alone have the highest level of reliance on first responders in these situations compared to divorced citizens who have the lowest level;

- reliance on the army in the first 72 hours after the occurrence of floods statistically significantly $(p<0.05)$, and mutually differs among citizens who live alone $(M=3.67$, $S D=1.25)$ and citizens who are divorced $(M=2.91, S D=1.53)$. Citizens who live alone have the highest level of reliance on the army in these situations compared to divorced citizens who have the lowest level;

- reliance on self-organized individuals in the first 72 hours after the occurrence of floods statistically significantly $(p<0.05)$, and mutually differs among citizens who live alone $(M=3.20$, $S D=1.32$ ) and citizens who have lost their spouses $(M=2.60, S D=1.37)$. Citizens who live alone have the highest level of reliance on self-organized individuals in such situations compared to citizens who have lost their spouses who have the lowest level;

- awareness of potential flood risks in local community statistically significantly $(p<0.05)$, and mutually differs among citizens who are in a relationship $(M=2.88, S D=1.95)$ and citizens who have lost their spouses $(M=1.95, S D=1.13)$. For citizens who are in a relationship have the highest level of awareness in relation to citizens who have lost their spouses and who have the lowest level;

- reason ,My help would not mean much” for not engaging in the field to help other people statistically significantly $(p<0.05)$, and mutually differs among citizens who live alone $(\mathrm{M}=2.55, \mathrm{SD}=1.12)$ and who are divorced $(\mathrm{M}=2.37, \mathrm{SD}=1.27)$. Citizens who live alone have the highest level of agreement with the stated reasons compared to divorced citizens who have lowest level; 
Marital Status of Citizens and Floods: Citizen Preparedness for Response to Natural Disasters

- reasons „Others have helped enough" for not engaging in the field to help other people statistically significantly $(p<0.05)$, and mutually differs among citizens who are married $(M=2.78, S D=1.22)$ and who are divorced $(M=2.29, S D=1.23)$. Citizens who are married have the highest level of agreement with the stated reason compared to divorced citizens who have the lowest level;

- reason ,it is a job of competent state authorities" for not engaging in the field to help other people statistically significantly $(p<0.05)$, and mutually differs among citizens who have lost their spouses $(M=3.84, S D=104)$ and who are divorced $(M=2.60, S D=1.46)$. Citizens who have lost their spouses have the highest level of agreement with the stated reason compared to divorced citizens who have the lowest level;

- reason ,,I expected primarily be engaged citizens from flood-affected areas" for not engaging engage in the field to help other people statistically significantly $(p<0.05)$, and mutually differs among citizens who have lost their spouses $(M=3,24, S D=1.23)$, and citizens who live alone $(M=2.68, S D=1.22)$. Citizens who have lost their spouses have the highest level of agreement with the stated reason compared to divorced citizens who have the lowest level;

- reason ,,I did not have enough time" for not engaging in the field to help other people statistically significant $(p<0.05)$, and mutually differs among citizens who have lost their spouses $(M=3.26, S D=1.52)$ and who are divorced $(M=2.25, S D=1.21)$. Citizens who have lost their spouses have the highest level of agreement with the stated reason compared to divorced citizens who have the lowest level;

- assessment of efficiency of the police response to natural disasters caused by floods statistically significantly $(p<0.05)$, and mutually differs among citizens who are married $(M=3.32, S D=1.27)$ and divorced people $(M=2,84, S D=1.29)$. Citizens who are married have the highest level of efficiency evaluation of police response in relation to divorced citizens who have the lowest level;

- assessment of efficiency of response of first responders in natural disasters caused by floods statistically significantly $(p<0.05)$, and mutually differs among citizens who are engaged $(M=3.78, S D=1.21)$ and divorced people $(M=308, S D=1.39)$. Citizens who are engaged recorded the highest level of efficiency evaluation of response of first responders in relation to divorced citizens who recorded the lowest level;

- assessment of efficiency of emergency response medical assistance in natural disasters caused by floods statistically significantly $(\mathrm{p}<0.05)$, and mutually differs among citizens who are engaged $(M=3.82, S D=1.21)$ and divorced people $(M=306, S D=1.36)$. Citizens who are engaged recorded the highest level of efficiency evaluation of response of emergency service in relation to divorced citizens who recorded the lowest level;

- assessment of efficiency of military response to natural disasters caused by floods statistically significantly $(p<0.05)$, and mutually differs among citizens who are engaged $(M=3.80, S D=1.43)$ and divorced people $(M=2.96, S D=1.58)$. Citizens who are engaged recorded the highest level of efficiency evaluation of military response in relation to divorced citizens who recorded the lowest level;

- assessment of efficiency of stuff for emergency situations to natural disasters caused by floods statistically significantly $(p<0.05)$, and mutually differs among citizens who are engaged $(M=3.49, S D=1.48)$ and divorced people $(M=2.49, S D=1.39)$. Citizens who are engaged recorded the highest level of efficiency evaluation of response of stuff for emergency situations in relation to divorced citizens who recorded the lowest level. 
VOJNO DELO, 8/2016

Table 4 - Results of one-way ANOVA of different marital status groups and continuous dependent variables on the perception of preparedness for response

\begin{tabular}{|c|c|c|c|c|}
\hline \multicolumn{5}{|c|}{ Homogeneity of variance test } \\
\hline & Levene Statistic & df1 & df2 & Sig. \\
\hline Individual preparedness & 14,006 & 5 & 2465 & 000 \\
\hline Household preparedness & 6,634 & 5 & 2473 &, 000 \\
\hline Preparedness of loc. community & 7,206 & 5 & 2458 & .000 \\
\hline State preparedness & 5,260 & 5 & 2463 &, 000 \\
\hline Personal abilities & 7,357 & 5 & 2450 &, 000 \\
\hline Importance of taken measures & 1,581 & 5 & 2459 & ,162* \\
\hline ISS & 2,062 & 5 & 2426 &, $067^{*}$ \\
\hline I am not threatened & ,606 & 5 & 2441 & ,695* \\
\hline I have no time for that & 1,916 & 5 & 2418 &, $088^{*}$ \\
\hline It is very expensive & 3,458 & 5 & 2408 &, 004 \\
\hline It will not influence on safety & 2,341 & 5 & 2413 &, 039 \\
\hline I am not capable & 4,393 & 5 & 2407 & 001 \\
\hline I have no support & ,827 & 5 & 2419 &, $530^{*}$ \\
\hline I can not prevent it & 1,971 & 5 & 2404 &, $080^{*}$ \\
\hline Household members & 8,709 & 5 & 2431 &, 000 \\
\hline Neighbors & 4,417 & 5 & 2432 & 001 \\
\hline $\begin{array}{l}\text { Non-governmental humanitarian } \\
\text { organizations }\end{array}$ & 3,145 & 5 & 2416 & ,008 \\
\hline $\begin{array}{l}\text { International humanitarian } \\
\text { organizations }\end{array}$ & 1,715 & 5 & 2415 & ,128* \\
\hline Religious community & 4,302 & 5 & 2413 & 001 \\
\hline Police & ,441 & 5 & 2429 & ,820* \\
\hline First responders & 7,183 & 5 & 2432 &, 000 \\
\hline Emergency service & 3,219 & 5 & 2431 &, 007 \\
\hline Army & 5,065 & 5 & 2433 &, 000 \\
\hline Self-organized individuals & 1,948 & 5 & 2431 & ,083* \\
\hline Awareness & 1,659 & 5 & 2466 & ,141* \\
\hline Interest & 3,920 & 5 & 2454 &, 002 \\
\hline Help would not mean much & 4,654 & 5 & 2317 &, 000 \\
\hline Others have helped & 4,627 & 5 & 2316 &, 000 \\
\hline Job of state authorities & 3,989 & 5 & 2311 & 001 \\
\hline Citizens in flooded areas & ,993 & 5 & 2293 & ,421* \\
\hline Lack of time & 3,594 & 5 & 2303 &, 003 \\
\hline It is too costly & 4,458 & 5 & 2301 &, 000 \\
\hline Efficiency of the police & 2,615 & 5 & 2408 & ,023 \\
\hline Efficiency of first responders & 2,428 & 5 & 2409 & 033 \\
\hline Efficiency of emergency service & 1,421 & 5 & 2408 & ,213* \\
\hline Efficiency of the army & 9,586 & 5 & 2395 & .000 \\
\hline $\begin{array}{l}\text { Efficiency of stuff for emergency } \\
\text { situations }\end{array}$ & 1,501 & 5 & 2405 & ,186* \\
\hline
\end{tabular}

${ }^{*}$ Presumption of homogeneity of variance is not violated - Sig. $>0,05$ 
Marital Status of Citizens and Floods: Citizen Preparedness for Response to Natural Disasters

\begin{tabular}{|c|c|c|c|c|c|c|}
\hline \multicolumn{7}{|c|}{ ANOVA } \\
\hline & & $\begin{array}{l}\text { Sum of } \\
\text { Squares }\end{array}$ & df & $\begin{array}{l}\text { Mean } \\
\text { Square }\end{array}$ & $\mathbf{F}$ & Sig. \\
\hline \multirow{3}{*}{ Individual preparedness } & Different group & 51,474 & 5 & 10,295 & 9,461 &, 000 \\
\hline & Within a group & 2682,117 & 2465 & 1,088 & & \\
\hline & Total & 2733,591 & 2470 & & & \\
\hline \multirow{3}{*}{ Household preparedness } & Different group & 23,730 & 5 & 4,746 & 4,961 & 000 \\
\hline & Within a group & 2365,815 & 2473 & 957 & & \\
\hline & Total & 2389,546 & 2478 & & & \\
\hline \multirow{3}{*}{$\begin{array}{l}\text { Preparedness of loc. } \\
\text { community }\end{array}$} & Different group & 16,983 & 5 & 3,397 & 2,763 &, 017 \\
\hline & Within a group & 3021,867 & 2458 & 1,229 & & \\
\hline & Total & 3038,851 & 2463 & & & \\
\hline \multirow{3}{*}{ State preparedness } & Different group & 10,034 & 5 & 2,007 & 1,501 & , 186 \\
\hline & Within a group & 3293,036 & 2463 & 1,337 & & \\
\hline & Total & 3303,070 & 2468 & & & \\
\hline \multirow{3}{*}{ Personal abilities } & Different group & 84,333 & 5 & 16,867 & 16,146 & ,000 \\
\hline & Within a group & 2559,348 & 2450 & 1,045 & & \\
\hline & Total & 2643,681 & 2455 & & & \\
\hline \multirow{3}{*}{$\begin{array}{l}\text { Importance of taken } \\
\text { measures }\end{array}$} & Different group & 63,239 & 5 & 12,648 & 9,957 &, $000^{*}$ \\
\hline & Within a group & 3123,634 & 2459 & 1,270 & & \\
\hline & Total & 3186,872 & 2464 & & & \\
\hline \multirow{3}{*}{ First responders } & Different group & 14,332 & 5 & 2,866 & 1,624 & ,150 \\
\hline & Within a group & 4281,666 & 2426 & 1,765 & & \\
\hline & Total & 4295,998 & 2431 & & & \\
\hline \multirow{3}{*}{ I an not threatened } & Different group & 80,339 & 5 & 16,068 & 7,730 &, $000^{\star}$ \\
\hline & Within a group & 5073,752 & 2441 & 2,079 & & \\
\hline & Total & 5154,092 & 2446 & & & \\
\hline \multirow{3}{*}{ I have no time for that } & Different group & 29,007 & 5 & 5,801 & 3,235 &, $006^{*}$ \\
\hline & Within a group & 4336,339 & 2418 & 1,793 & & \\
\hline & Total & 4365,346 & 2423 & & & \\
\hline \multirow{3}{*}{ It is very expensive } & Different group & 23,798 & 5 & 4,760 & 2,737 &, 018 \\
\hline & Within a group & 4187,559 & 2408 & 1,739 & & \\
\hline & Total & 4211,357 & 2413 & & & \\
\hline \multirow{3}{*}{ It will not influence on safety } & Different group & 36,425 & 5 & 7,285 & 4,275 &, 001 \\
\hline & Within a group & 4112,058 & 2413 & 1,704 & & \\
\hline & Total & 4148,483 & 2418 & & & \\
\hline \multirow{3}{*}{ I an not capable } & Different group & 7,937 & 5 & 1,587 & ,904 & ,478 \\
\hline & Within a group & 4228,471 & 2407 & 1,757 & & \\
\hline & Total & 4236,408 & 2412 & & & \\
\hline \multirow{3}{*}{ I have no support } & Different group & 35,517 & 5 & 7,103 & 4,155 &, $001^{*}$ \\
\hline & Within a group & 4136,029 & 2419 & 1,710 & & \\
\hline & Total & 4171,546 & 2424 & & & \\
\hline \multirow{3}{*}{ I can not prevent it } & Different group & 26,990 & 5 & 5,398 & 2,933 &, $012^{*}$ \\
\hline & Within a group & 4424,527 & 2404 & 1,840 & & \\
\hline & Total & 4451,517 & 2409 & & & \\
\hline \multirow{3}{*}{ Household members } & Different group & 68,956 & 5 & 13,791 & 9,211 &, 000 \\
\hline & Within a group & 3639,755 & 2431 & 1,497 & & \\
\hline & Total & 3708,711 & 2436 & & & \\
\hline
\end{tabular}




\begin{tabular}{|c|c|c|c|c|c|c|}
\hline \multicolumn{7}{|c|}{ ANOVA } \\
\hline & & $\begin{array}{l}\text { Sum of } \\
\text { Squares }\end{array}$ & df & $\begin{array}{l}\text { Mean } \\
\text { Square }\end{array}$ & $\mathbf{F}$ & Sig. \\
\hline \multirow{3}{*}{ Neighbors } & Different group & 111,087 & 5 & 22,217 & 14,572 &, 000 \\
\hline & Within a group & 3707,954 & 2432 & 1,525 & & \\
\hline & Total & 3819,041 & 2437 & & & \\
\hline \multirow{3}{*}{$\begin{array}{l}\text { Non-governmental } \\
\text { humanitarian organizations }\end{array}$} & Different group & 44,783 & 5 & 8,957 & 6,573 &, 000 \\
\hline & Within a group & 3291,989 & 2416 & 1,363 & & \\
\hline & Total & 3336,772 & 2421 & & & \\
\hline \multirow{3}{*}{$\begin{array}{l}\text { International humanitarian } \\
\text { organizations }\end{array}$} & Different group & 28,029 & 5 & 5,606 & 4,271 &, $001^{*}$ \\
\hline & Within a group & 3169,501 & 2415 & 1,312 & & \\
\hline & Total & 3197,530 & 2420 & & & \\
\hline \multirow{3}{*}{ Religious community } & Different group & 8,255 & 5 & 1,651 & 1,093 & ,362 \\
\hline & Within a group & 3644,023 & 2413 & 1,510 & & \\
\hline & Total & 3652,278 & 2418 & & & \\
\hline \multirow{3}{*}{ Police } & Different group & 28,208 & 5 & 5,642 & 3,264 &, $006^{*}$ \\
\hline & Within a group & 4198,016 & 2429 & 1,728 & & \\
\hline & Total & 4226,224 & 2434 & & & \\
\hline \multirow{3}{*}{ First responders } & Different group & 51,466 & 5 & 10,293 & 6,854 &, 000 \\
\hline & Within a group & 3652,339 & 2432 & 1,502 & & \\
\hline & Total & 3703,805 & 2437 & & & \\
\hline \multirow{3}{*}{ Emergency medical service } & Different group & 25,099 & 5 & 5,020 & 3,268 & ,006 \\
\hline & Within a group & 3734,482 & 2431 & 1,536 & & \\
\hline & Total & 3759,581 & 2436 & & & \\
\hline \multirow{3}{*}{ Army } & Different group & 59,291 & 5 & 11,858 & 6,673 &, 000 \\
\hline & Within a group & 4323,541 & 2433 & 1,777 & & \\
\hline & Total & 4382,832 & 2438 & & & \\
\hline \multirow{3}{*}{ Self-organized individuals } & Different group & 36,343 & 5 & 7,269 & 4,062 &, $001^{*}$ \\
\hline & Within a group & 4350,010 & 2431 & 1,789 & & \\
\hline & Total & 4386,354 & 2436 & & & \\
\hline \multirow{3}{*}{ Awareness } & Different group & 65,445 & 5 & 13,089 & 8,444 &, $000^{*}$ \\
\hline & Within a group & 3822,432 & 2466 & 1,550 & & \\
\hline & Total & 3887,877 & 2471 & & & \\
\hline \multirow{3}{*}{ Interest } & Different group & 65,729 & 5 & 13,146 & 9,690 &, 000 \\
\hline & Within a group & 3329,319 & 2454 & 1,357 & & \\
\hline & Total & 3395,048 & 2459 & & & \\
\hline \multirow{3}{*}{ Help would not mean much } & Different group & 96,328 & 5 & 19,266 & 12,619 &, 000 \\
\hline & Within a group & 3537,388 & 2317 & 1,527 & & \\
\hline & Total & 3633,716 & 2322 & & & \\
\hline \multirow{3}{*}{ Others have helped } & Different group & 22,647 & 5 & 4,529 & 3,048 &, 010 \\
\hline & Within a group & 3441,200 & 2316 & 1,486 & & \\
\hline & Total & 3463,847 & 2321 & & & \\
\hline \multirow{3}{*}{ Job of state authorities } & Different group & 70,674 & 5 & 14,135 & 9,294 &, 000 \\
\hline & Within a group & 3514,815 & 2311 & 1,521 & & \\
\hline & Total & 3585,489 & 2316 & & & \\
\hline \multirow{3}{*}{ Citizens in flooded areas } & Different group & 23,582 & 5 & 4,716 & 3,145 &, $008^{*}$ \\
\hline & Within a group & 3438,832 & 2293 & 1,500 & & \\
\hline & Total & 3462,414 & 2298 & & & \\
\hline
\end{tabular}


Marital Status of Citizens and Floods: Citizen Preparedness for Response to Natural Disasters

\begin{tabular}{|c|c|c|c|c|c|c|}
\hline \multicolumn{7}{|c|}{ ANOVA } \\
\hline & & $\begin{array}{l}\text { Sum of } \\
\text { Squares }\end{array}$ & df & $\begin{array}{l}\text { Mean } \\
\text { Square }\end{array}$ & $\mathbf{F}$ & Sig. \\
\hline \multirow{3}{*}{ Lack of time } & Different group & 46,125 & 5 & 9,225 & 5,545 &, 000 \\
\hline & Within a group & 3831,327 & 2303 & 1,664 & & \\
\hline & Total & 3877,453 & 2308 & & & \\
\hline \multirow{3}{*}{ It is too costly } & Different group & 4,725 & 5 & ,945 & ,657 & ,656 \\
\hline & Within a group & 3309,249 & 2301 & 1,438 & & \\
\hline & Total & 3313,974 & 2306 & & & \\
\hline \multirow{3}{*}{ Efficiency of the police } & Different group & 23,488 & 5 & 4,698 & 2,872 & ,014 \\
\hline & Within a group & 3938,703 & 2408 & 1,636 & & \\
\hline & Total & 3962,191 & 2413 & & & \\
\hline \multirow{3}{*}{ Efficiency of first responders } & Different group & 34,173 & 5 & 6,835 & 4,121 & ,001 \\
\hline & Within a group & 3995,576 & 2409 & 1,659 & & \\
\hline & Total & 4029,749 & 2414 & & & \\
\hline \multirow{3}{*}{$\begin{array}{l}\text { Efficiency of emergency } \\
\text { service }\end{array}$} & Different group & 42,705 & 5 & 8,541 & 5,734 &, $000^{*}$ \\
\hline & Within a group & 3586,769 & 2408 & 1,490 & & \\
\hline & Total & 3629,473 & 2413 & & & \\
\hline \multirow{3}{*}{ Efficiency of the army } & Different group & 71,787 & 5 & 14,357 & 8,197 & 000 \\
\hline & Within a group & 4195,029 & 2395 & 1,752 & & \\
\hline & Total & 4266,816 & 2400 & & & \\
\hline \multirow{3}{*}{$\begin{array}{l}\text { Efficiency of stuff for } \\
\text { emergency situations }\end{array}$} & Different group & 42,016 & 5 & 8,403 & 4,526 &, $000^{*}$ \\
\hline & Within a group & 4464,936 & 2405 & 1,857 & & \\
\hline & Total & 4506,952 & 2410 & & & \\
\hline
\end{tabular}

* There is a statistically significant difference between the means of dependent variables in 6 groups - Sig. $\leq 0.05$

\begin{tabular}{|c|c|c|c|c|c|}
\hline \multicolumn{6}{|c|}{ Robust Tests of Equality of Means } \\
\hline & & Statistic $^{a}$ & df1 & df2 & Sig. \\
\hline \multirow[b]{2}{*}{ Individual preparedness } & Welch & 6,194 & 5 & 283,466 &, $000^{*}$ \\
\hline & $\begin{array}{l}\text { Brown - } \\
\text { Forsythe }\end{array}$ & 7,358 & 5 & 442,488 &, $000^{*}$ \\
\hline \multirow[b]{2}{*}{ Household preparedness } & Welch & 4,001 & 5 & 290,962 &, $002^{*}$ \\
\hline & $\begin{array}{l}\text { Brown - } \\
\text { Forsythe }\end{array}$ & 4,363 & 5 & 537,780 &, $001^{*}$ \\
\hline \multirow[b]{2}{*}{ Preparedness of local community } & Welch & 2,496 & 5 & 286,825 &, $031^{*}$ \\
\hline & $\begin{array}{l}\text { Brown - } \\
\text { Forsythe }\end{array}$ & 2,486 & 5 & 539,198 &, $031^{*}$ \\
\hline \multirow[b]{2}{*}{ State preparedness } & Welch & 1,290 & 5 & 288,458 &, 268 \\
\hline & $\begin{array}{l}\text { Brown - } \\
\text { Forsythe }\end{array}$ & 1,300 & 5 & 510,577 & ,262 \\
\hline \multirow[b]{2}{*}{ Personal abilities } & Welch & 11,592 & 5 & 289,008 &, $000^{*}$ \\
\hline & $\begin{array}{l}\text { Brown - } \\
\text { Forsythe }\end{array}$ & 13,460 & 5 & 513,730 &, $000^{*}$ \\
\hline \multirow[b]{2}{*}{ It is very expansive } & Welch & 2,849 & 5 & 271,781 &, $016^{*}$ \\
\hline & $\begin{array}{l}\text { Brown - } \\
\text { Forsythe }\end{array}$ & 2,621 & 5 & 497,971 &, $024^{*}$ \\
\hline
\end{tabular}




\begin{tabular}{|c|c|c|c|c|c|}
\hline \multicolumn{6}{|c|}{ Robust Tests of Equality of Means } \\
\hline & & Statistic $^{a}$ & df1 & df2 & Sig. \\
\hline \multirow[b]{2}{*}{ It will not influence on safety } & Welch & 4,009 & 5 & 273,515 &, $002^{*}$ \\
\hline & $\begin{array}{l}\text { Brown - } \\
\text { Forsythe }\end{array}$ & 4,210 & 5 & 563,688 &, $001^{*}$ \\
\hline \multirow[b]{2}{*}{ I am not capable } & Welch & ,927 & 5 & 272,742 & ,464 \\
\hline & $\begin{array}{l}\text { Brown - } \\
\text { Forsythe }\end{array}$ & 850 & 5 & 534,877 &, 515 \\
\hline \multirow[b]{2}{*}{ Household members } & Welch & 5,483 & 5 & 283,628 &, $000^{*}$ \\
\hline & $\begin{array}{l}\text { Brown - } \\
\text { Forsythe }\end{array}$ & 8,121 & 5 & 535,636 &, $000^{*}$ \\
\hline \multirow[b]{2}{*}{ Neighbors } & Welch & 11,614 & 5 & 293,762 &, $000^{*}$ \\
\hline & $\begin{array}{l}\text { Brown - } \\
\text { Forsythe }\end{array}$ & 14,645 & 5 & 641,758 &, $000^{*}$ \\
\hline \multirow{2}{*}{$\begin{array}{l}\text { Non-governmental humanitarian } \\
\text { organizations }\end{array}$} & Welch & 6,465 & 5 & 288,496 &, $000^{*}$ \\
\hline & $\begin{array}{l}\text { Brown - } \\
\text { Forsythe }\end{array}$ & 6,813 & 5 & 637,446 &, $000^{*}$ \\
\hline \multirow[b]{2}{*}{ Religious community } & Welch & 1,031 & 5 & 289,112 &, 400 \\
\hline & $\begin{array}{l}\text { Brown - } \\
\text { Forsythe }\end{array}$ & 1,080 & 5 & 593,876 & ,370 \\
\hline \multirow[b]{2}{*}{ First responders } & Welch & 5,224 & 5 & 285,146 &, $000^{*}$ \\
\hline & $\begin{array}{l}\text { Brown - } \\
\text { Forsythe }\end{array}$ & 5,763 & 5 & 483,547 &, $000^{*}$ \\
\hline \multirow[b]{2}{*}{ Emergency medical service } & Welch & 2,654 & 5 & 289,080 &, $023^{*}$ \\
\hline & $\begin{array}{l}\text { Brown - } \\
\text { Forsythe }\end{array}$ & 2,865 & 5 & 542,564 &, $015^{*}$ \\
\hline \multirow[b]{2}{*}{ Army } & Welch & 5,286 & 5 & 285,106 &, $000^{*}$ \\
\hline & $\begin{array}{l}\text { Brown - } \\
\text { Forsythe }\end{array}$ & 5,645 & 5 & 484,376 &, $000^{*}$ \\
\hline \multirow[b]{2}{*}{ Interest } & Welch & 7,980 & 5 & 287,224 &, $000^{*}$ \\
\hline & $\begin{array}{l}\text { Brown - } \\
\text { Forsythe }\end{array}$ & 8,575 & 5 & 520,577 &, $000^{*}$ \\
\hline \multirow[b]{2}{*}{ Help would not mean much } & Welch & 9,024 & 5 & 269,832 &, $000^{*}$ \\
\hline & $\begin{array}{l}\text { Brown - } \\
\text { Forsythe }\end{array}$ & 12,046 & 5 & 492,920 &, $000^{*}$ \\
\hline \multirow[b]{2}{*}{ Others have helped } & Welch & 2,940 & 5 & 273,929 &, $013^{*}$ \\
\hline & $\begin{array}{l}\text { Brown - } \\
\text { Forsythe }\end{array}$ & 2,725 & 5 & 474,929 &, $019^{*}$ \\
\hline \multirow[b]{2}{*}{ Job of state authorities } & Welch & 11,653 & 5 & 276,276 &, $000^{*}$ \\
\hline & $\begin{array}{l}\text { Brown - } \\
\text { Forsythe }\end{array}$ & 8,878 & 5 & 523,069 &, $000^{*}$ \\
\hline \multirow[b]{2}{*}{ Lack of time } & Welch & 4,602 & 5 & 266,013 &, $000^{*}$ \\
\hline & $\begin{array}{l}\text { Brown - } \\
\text { Forsythe }\end{array}$ & 5,157 & 5 & 479,765 &, $000^{*}$ \\
\hline
\end{tabular}


Marital Status of Citizens and Floods: Citizen Preparedness for Response to Natural Disasters

\begin{tabular}{|c|c|c|c|c|c|}
\hline \multicolumn{6}{|c|}{ Robust Tests of Equality of Means } \\
\hline & & Statistic $^{a}$ & df1 & df2 & Sig. \\
\hline \multirow[b]{2}{*}{ It is too costly } & Welch &, 585 & 5 & 267,120 & ,712 \\
\hline & $\begin{array}{l}\text { Brown - } \\
\text { Forsythe }\end{array}$ & ,618 & 5 & 557,160 & ,686 \\
\hline \multirow[b]{2}{*}{ Efficiency of the police } & Welch & 2,783 & 5 & 282,747 & ,018* \\
\hline & $\begin{array}{l}\text { Brown - } \\
\text { Forsythe }\end{array}$ & 2,597 & 5 & 503,345 &, $025^{*}$ \\
\hline \multirow[b]{2}{*}{ Efficiency of first responders } & Welch & 3,830 & 5 & 280,082 &, $002^{*}$ \\
\hline & $\begin{array}{l}\text { Brown - } \\
\text { Forsythe }\end{array}$ & 3,810 & 5 & 551,698 &, $002^{*}$ \\
\hline \multirow[b]{2}{*}{ Efficiency of the army } & Welch & 6,092 & 5 & 277,856 &, $000^{*}$ \\
\hline & $\begin{array}{l}\text { Brown - } \\
\text { Forsythe }\end{array}$ & 6,936 & 5 & 497,771 &, $000^{*}$ \\
\hline
\end{tabular}

* There is a statistically significant difference between the means of dependent variables in 6 groups - Sig. $\leq 0.05$

The results of Chi-square test of independence $(x 2)$ showed a statistically significant relationship between marital status and the following variables of knowledge on natural disasters caused by floods: knowledge on floods $(p=0.000<0.05, v=0.08$ - medium influence); familiarity with safety procedures $(p=0.000<0.05, v=0.10$ - medium influence); evacuation ( $p=0.000<0.05, v=0.09$ - medium impact); education at school $(p=0.000<0.05, v=0.08$ - medium influence); education at work $(p=0.000<0.05, v=0.13$ - medium influence); elders, disabled $(p=0.000<0.05, v=0.08$ - medium influence); help - elders, disabled $(p=0.000<0.05, v=0.13$ - medium influence); official warning $(p=0.000<0.05, v=0.14$ - medium influence); potential infection $(p=0.000<0.05$, $v=0.13$ - medium influence); water valve $(p=0.000<0.05, v=0.16$ - medium influence); gas valve $(p=0.000<0.05, v=0.14$ - medium influence); electricity switch $(p=0.000<0.05, v=0.12$ - medium influence); handling valve for water $(p=0.000$ $<0.05, v=0.15$ - medium influence); handling valve for gas $(p=0.000<0.05, v=0.18$ medium influence); handling electricity switch $(p=0.000<0.05, v=0.12$ - medium influence); information from household members $(p=0.000<0.05, v=0.10$ - medium influence); information from neighbors ( $p=0.000<0.05, v=0.11$ - medium influence); information from a friend ( $p=0.000<0.05, v=0.12$ - medium influence); information at school ( $p=0.000<0.05, v=0.10$ - medium influence); information through informal system ( $p=0.000<0.05, v=0.10$ - medium influence); information at work $(p=0.000$ $<0.05, v=0.12$ - medium influence); information on television $(p=0.000<0.05, v=0.11$ - medium influence); information over the Internet $(p=0.000<0.05, v=0.14$ - medium influence); desire for training ( $p=0.000<0.05, v=0.09$ - medium influence); TV $(p=0.000<0.05, v=0.11$ - medium influence); radio $(p=0.000<0.05, v=0.10-$ medium influence); video games $(p=0.001<0.05, v=0.09$ - medium influence); internet $(p=0.000<0.05, v=0.15$ - medium influence) (Table 3$)$. 
The results indicate that:

- Married citizens: in the highest percentage - know what flood is (83.7\%) are familiar with viruses and infections that accompany the period during and after floods $(53.6 \%)$, know where in local community elders, disabled and infants live (46.3\%) know safety procedures for responding during floods $(27.6 \%)$, would evacuate to a friend's place $(36.8 \%)$, say that someone at work educated them on floods $(39.1 \%)$, know how to handle the valve for water $(81.9 \%)$, valve for gas $(60.5 \%)$, electricity switch $(78.4 \%)$, got information about floods in the press (34.1\%); in the smallest percentage - they got information about floods at school $(11.9 \%)$;

- Divorced citizens in the highest percentage - would evacuate to neighbors (18.1\%), they know where electricity switch is $(94.3 \%)$, gained information about floods from household members $(37.6 \%)$, want to be educated on the radio $(26.1 \%)$; in the smallest percentage know what flood is $(68 \%)$, would evacuate to the upper floor of the house $(31.9 \%)$, would evacuate to detention centers $(10.6 \%)$, say that someone at primary/secondary school $(19.4 \%)$ and within family $(32.3 \%)$ educated them about floods, they know what to do after an official warning about the approach of a flood wave (34.7\%), gained information about floods at faculty (3.2\%), acquired information about floods through an informal system of education $(2.2 \%)$, the press $(22.6 \%)$ want to be educated through video-games $(0.1 \%)$;

- Citizens who have lost their spouses: in the highest percentage - would be evacuated in collective centers $(30.9 \%)$, they know what helped is required by elders, disabled and infants $(60 \%)$, they know where water valve is $(92 \%)$, gas valve $(72.9 \%)$, gained information about floods from neighbors (33.8\%) want to be educated on television $(86.5 \%)$; in the smallest percentage - know safety procedures for responding during floods $(12.3 \%)$ are familiar with viruses and infections that accompany the period during and after floods, would evacuate to neighbors' places (1.1\%), know where in local community elders, disabled and infants live (30.3\%), gained information about floods from friends (4.4\%) over the Internet (4.4\%), want to undergo some form of training for dealing with natural disasters caused by floods (9\%), they want to be educated over the Internet (4.5\%);

- Citizens who are engaged in the greatest percentage - would evacuate to the upper floor of the house $(40.4 \%)$, gained information about floods at faculty $(9.7 \%)$, an informal system of education (12.9\%); in the smallest percentage - acquired information about floods from household members (16.1\%) want to be educated on the radio $(1.6 \%)$;

- Citizens who are not in a relationship: in the highest percentage - point out that someone at primary/secondary school educated them on floods (23\%), acquired information about floods from friends $(16.7 \%)$, they would like to undergo some form of training for dealing with natural disasters caused by floods $(44.8 \%)$ want to be educated through video-games (3.6\%); in the smallest percentage - point out that someone at work educated them about floods (21.4\%), they know what to do after an official warning about the approach of a flood wave (19.5\%), they know where water valve is $(66.4 \%)$;

- Citizens who are in a relationship: in the highest percentage - point out that someone within family educated them about floods (47.9\%), gained information about floods at school $(20.6 \%)$ over the Internet $(39.5 \%)$, they want to be educated over the Internet $(33.2 \%)$; in the smallest percentage know what help is required by elders, disabled and infants $(40.8 \%)$, they know where electricity switch is $(69.1 \%)$, know how to handle water valve to $(62.1 \%)$, gas valve $(35 \%)$, gained information about floods from neighbors (10.9\%) want to gain information through television (56\%). 
Marital Status of Citizens and Floods: Citizen Preparedness for Response to Natural Disasters

Table 5 - Review of the results of Chi-square test of independence (X2) of marital status and knowledge as an element of preparedness for response

\begin{tabular}{|c|c|c|c|c|}
\hline & value & df & Asymp. Sig. (2 - sided) & Cramer's v \\
\hline Knowledge on floods & 35,270 & 10 &, $000^{*}$ &, 086 \\
\hline Familiarity with safety procedures & 43,971 & 10 &, $000^{*}$ & 098 \\
\hline Evacuation & 63,277 & 20 &, $000^{*}$ & 084 \\
\hline Education at school & 34,095 & 10 &, $000^{*}$ &, 085 \\
\hline Education within family & 24,469 & 10 &, 006 &, 072 \\
\hline Education at work & 85,838 & 10 &, $000^{*}$ & ,137 \\
\hline Elders, disabled, infants & 33,072 & 10 &, $000^{*}$ & ,084 \\
\hline Consent for evacuation & 3,381 & 5 & 642 &, 038 \\
\hline Help - elders, disabled & 88,520 & 10 &, $000^{*}$ &, 135 \\
\hline Neighbors - independently & 24,407 & 10 &, 007 & 072 \\
\hline Flood risk map & 24,125 & 10 & 007 & 071 \\
\hline Official warning & 98,381 & 10 &, $000^{*}$ & ,146 \\
\hline Potential infection & 87,595 & 10 &, $000^{*}$ & ,136 \\
\hline Water valve & 130,492 & 10 &, $000^{*}$ & 165 \\
\hline Gas valve & 78,524 & 10 &, $000^{*}$ & ,143 \\
\hline Electricity switch & 70,615 & 10 &, $000^{*}$ & ,124 \\
\hline Handling water valve & 118,782 & 10 &, $000^{*}$ & 157 \\
\hline Handling gas valve & 127,672 & 10 &, $000^{*}$ & ,181 \\
\hline Handling electricity switch & 71,072 & 10 &, $000^{*}$ & ,124 \\
\hline Information from household members & 27,947 & 5 &, $000^{*}$ & ,109 \\
\hline Information from neighbors & 31,574 & 5 &, $000^{*}$ & 116 \\
\hline Information form friends & 39,060 & 5 &, $000^{*}$ & ,129 \\
\hline Information form relatives & 6,865 & 5 & 231 &, 054 \\
\hline Information at school & 26,112 & 5 &, $000^{*}$ &, 106 \\
\hline Information at faculty & 8,533 & 5 &, 129 & 060 \\
\hline Information through an informal system & 24,359 & 5 &, $000^{*}$ & ,103 \\
\hline Information at work & 34,584 & 5 &, $000^{*}$ &, 122 \\
\hline Information in religious community & 7,586 & 5 & ,181 & 057 \\
\hline Information on television & 30,254 & 5 &, $000^{*}$ & ,113 \\
\hline Information on the radio & 8,124 & 5 &, 150 & 059 \\
\hline Information from the press & 16,925 & 5 &, 006 &, 085 \\
\hline Information over the Internet & 49,340 & 5 &, $000^{*}$ & ,145 \\
\hline Trained & 5,483 & 5 &, 360 &, 048 \\
\hline Desire for training & 39,335 & 10 &, $000^{*}$ &, 092 \\
\hline Education through television & 29,324 & 5 &, $000^{*}$ &, 112 \\
\hline Education on the radio & 27,663 & 5 &, $000^{*}$ & ,109 \\
\hline Education through video-games & 22,005 & 5 &, $001^{*}$ &, 098 \\
\hline Education over the Internet & 55,052 & 5 &, $000^{*}$ & ,154 \\
\hline Education through lectures & 5,594 & 5 &, 348 &, 049 \\
\hline Informal system & 8,589 & 5 &, 127 &, 060 \\
\hline
\end{tabular}

* Statistically significant correlation $-p \leq 0.05$

One-way ANOVA was used to study the influence of marital status on continuous dependent variables of knowledge. Subjects were divided according to marital status in 6 groups (single, in a relationship, engaged, married, divorced, widow/widower). Firstly, using homogeneity of variance test it was examined equality of variances in the results for each of the 6 groups. Bearing in mind the results of Levene Statistic the assumption 
of homogeneity of variance is violated in all variables, except for the stuff for emergency situations $(p=0.054)$. Accordingly, it is presented the table ,,Robust Tests of Equality of Means" and the results of two tests, Welsh's (Welsh) and Brown's (Brown - Forsythe) tests that are resistant to violation of the assumption of homogeneity of variance.

According to the results, there is a statistically significant difference between the means of the groups in the following dependent continuous variables: level of knowledge ( $F=4.08$, $p=.001$, eta squared $=0.01$ - small influence); flood risk -1 year $(F=4.16, p=.001$, eta squared $=0.008$ - small influence); warning systems $(F=8.46, p=, 000$, eta squared $=0.01$ small influence); Police $(F=5.03, p=, 000$, eta squared $=0.01$ - small influence); first responders $(F=7.86, p=.000$, eta squared $=0.01$ - small influence); escape routes $(F=5.05$, $p=0.000$, eta squared $=0.008$ - small influence); nearby shelters $(F=5.49, p=.000$, eta squared $=0.01$ - a small influence); vulnerability assessment and plan $(F=6.37, p=.000$, eta squared $=0.011$ - a small influence) $($ Table 4$)$.

Subsequent comparisons using Tukey HSD shows that the mean of:

- level of knowledge about floods statistically significantly $(p<0.05)$, and mutually differs among citizens who live alone $(M=3.02, S D=1.01)$, engaged $(M=2.53, S D=1.35)$ citizens who have lost their spouses $(M=2.58, S D=1.02)$. Thus, it can be said that citizens who live alone recorded the highest level of knowledge about natural disasters caused by floods, while it is the lowest among citizens who are engaged;

- Assessment of risks of flooding within a year statistically significantly $(p<0.05)$, and mutually differs among citizens who are married $(M=2.65, S D=1.41)$, and citizens who are in a relationship $(M=242, S D=1.35)$. In married people, assessment of flooding risk is at a higher level compared to citizens who are in a relationship;

- Awareness of warning systems statistically significantly $(p<0.05)$, and mutually differs for citizens who have lost their spouses $(M=1.65, S D=0.86)$, who are married $(M=2.30, S D=1.20)$, which live alone $(M=2.25, S D=1.19)$ and divorced $(M=2.46$, $\mathrm{SD}=1.33$ ). Awareness of warning systems is at the highest level among citizens who are divorced, while the smallest among citizens who have lost their spouses;

- Awareness of duties of the police in natural disasters caused by floods statistically significantly $(p<0.05)$, and mutually differs for citizens who have lost their spouses $(M=2.12$, $S D=1.21)$ who live alone $(M=2.67, S D=1.21)$, and citizens who are in a relationship $(M=2.57, S D=1.15)$. Citizens who live alone largely marked that they are informed on duties of the police;

- Awareness of duties of first responders in natural disasters caused by floods statistically significantly $(p<0.05)$, and mutually differs for citizens who are engaged $(M=2.22, S D=1.22)$ live alone $(M=2.77, S D=1.22)$, in a relationship $(M=2.72, S D=1.13)$, and who are married $(M=2.87, S D=1.34)$. Citizens who are married to the greatest extent say that they are informed on duties of first responders in natural disaster caused by floods;

- Awareness of escape routes in natural disasters caused by floods statistically significantly $(p<0.05)$, and mutually differs for citizens who have lost their spouses $(M=1.84$ $S D=1.07)$ live alone $(M=2,45, S D=1.26)$, married $(M=2.46, S D=1.32)$. Married people mostly say that they are informed about escape routes in case of floods;

\footnotetext{
${ }^{1}$ Eta-squared $=$ sum of the squares of the different groups $/$ total sum of squares. Cohen classifies 0.01 as a small influence, 0.06 as a medium influence and 0.14 as a large influence (Cohen, 1988 284).
} 
- Awareness of nearby shelters in natural disasters statistically significantly $(p<0.05)$, and mutually differs for citizens who have lost their spouses $(M=1.89, S D=1.12)$ live alone $(\mathrm{M}=2.34, \mathrm{SD}=1.17)$, in ca relationship $(\mathrm{M}=2.42, \mathrm{SD}=1.14)$ and divorced $(\mathrm{M}=2.69$, $\mathrm{SD}=1.38$ ). Divorced people largely indicate that they are familiar with locations of nearby shelters;

- Awareness of vulnerability assessments and plans of protection and sleeping in natural disasters statistically significantly $(p<0.05)$ and mutually differs for citizens who are divorced $(M=2.75, S D=1.22)$, in a relationship $(M=2,35, S D=1.14)$, engaged $(M=2.11, S D=1.12)$, married $(M=2.25, S D=1.22)$, and who have lost their spouses $(M=1.91, S D=0.98)$. The most informed about vulnerability assessments and plans for responding are divorced people.

Table 6 - Results of one-way ANOVA of different marital status groups and continuous dependent variables of knowledge

\begin{tabular}{|l|c|c|c|c|}
\hline \multicolumn{5}{|c|}{ Homogeneity of variance test } \\
\hline & Levene Statistic & df1 & df2 & \multicolumn{1}{l|}{ Sig. } \\
\hline Level of knowledge & 6,617 & 5 & 2366 &, 000 \\
\hline Flooding risk - 1 year & 11,398 & 5 & 2458 &, 000 \\
\hline Flooding risk - 5 years & 4,400 & 5 & 2403 &, 001 \\
\hline Warning systems & 3,905 & 5 & 2412 &, 002 \\
\hline Police & 3,379 & 5 & 2419 &, 005 \\
\hline First responders & 6,007 & 5 & 2415 &, 000 \\
\hline Stuff for emergency situations & $\mathbf{2 , 1 7 9}$ & $\mathbf{5}$ & $\mathbf{2 4 1 3}$ &, $054^{*}$ \\
\hline Escape routes & 3,491 & 5 & 2410 &, 004 \\
\hline Nearby shelters & 2,581 & 5 & 2415 &, 025 \\
\hline Vulnerability assessment and plans & 2,392 & 5 & 2407 &, 036 \\
\hline
\end{tabular}

* The assumption of the equality of variance is not violated - Sig. $>0.05$

\begin{tabular}{|c|c|c|c|c|c|c|}
\hline \multicolumn{7}{|c|}{ ANOVA } \\
\hline & & $\begin{array}{c}\text { Sum of } \\
\text { Squares }\end{array}$ & df & $\begin{array}{l}\text { Mean } \\
\text { Square }\end{array}$ & $\mathbf{F}$ & Sig. \\
\hline \multirow{3}{*}{ Level of knowledge } & $\begin{array}{l}\text { Different } \\
\text { group }\end{array}$ & 25,756 & 5 & 5,151 & 4,965 & ,000 \\
\hline & $\begin{array}{l}\text { Within a } \\
\text { group }\end{array}$ & 2454,674 & 2366 & 1,037 & & \\
\hline & Total & 2480,430 & 2371 & & & \\
\hline \multirow{3}{*}{ Flooding risk - 1 year } & $\begin{array}{l}\text { Different } \\
\text { group }\end{array}$ & 36,534 & 5 & 7,307 & 4,008 & 001 \\
\hline & $\begin{array}{l}\text { Within a } \\
\text { group }\end{array}$ & 4481,167 & 2458 & 1,823 & & \\
\hline & Total & 4517,701 & 2463 & & & \\
\hline \multirow{3}{*}{ Flooding risk -5 years } & $\begin{array}{l}\text { Different } \\
\text { group }\end{array}$ & 19,850 & 5 & 3,970 & 2,083 & ,065 \\
\hline & $\begin{array}{l}\text { Within a } \\
\text { group }\end{array}$ & 4580,151 & 2403 & 1,906 & & \\
\hline & Total & 4600,001 & 2408 & & & \\
\hline
\end{tabular}




\begin{tabular}{|c|c|c|c|c|c|c|}
\hline \multirow{3}{*}{ Warning systems } & $\begin{array}{l}\text { Different } \\
\text { group }\end{array}$ & 37,419 & 5 & 7,484 & 5,328 &, 000 \\
\hline & $\begin{array}{l}\text { Within a } \\
\text { group }\end{array}$ & 3388,242 & 2412 & 1,405 & & \\
\hline & Total & 3425,661 & 2417 & & & \\
\hline \multirow{3}{*}{ Police } & $\begin{array}{l}\text { Different } \\
\text { group }\end{array}$ & 37,168 & 5 & 7,434 & 4,733 &, 000 \\
\hline & $\begin{array}{l}\text { Within a } \\
\text { group }\end{array}$ & 3799,348 & 2419 & 1,571 & & \\
\hline & Total & 3836,515 & 2424 & & & \\
\hline \multirow{3}{*}{ First responders } & $\begin{array}{l}\text { Different } \\
\text { group }\end{array}$ & 60,818 & 5 & 12,164 & 7,407 &, 000 \\
\hline & $\begin{array}{l}\text { Within a } \\
\text { group }\end{array}$ & 3965,718 & 2415 & 1,642 & & \\
\hline & Total & 4026,535 & 2420 & & & \\
\hline \multirow{3}{*}{ Stuff for emergency situations } & $\begin{array}{l}\text { Different } \\
\text { group }\end{array}$ & 25,896 & 5 & 5,179 & 3,183 & ,007 \\
\hline & $\begin{array}{l}\text { Within a } \\
\text { group }\end{array}$ & 3926,243 & 2413 & 1,627 & & \\
\hline & Total & 3952,140 & 2418 & & & \\
\hline \multirow{3}{*}{ Escape routes } & $\begin{array}{l}\text { Different } \\
\text { group }\end{array}$ & 31,701 & 5 & 6,340 & 3,889 & ,002 \\
\hline & $\begin{array}{l}\text { Within a } \\
\text { group }\end{array}$ & 3928,988 & 2410 & 1,630 & & \\
\hline & Total & 3960,689 & 2415 & & & \\
\hline \multirow{3}{*}{ Nearby shelters } & $\begin{array}{l}\text { Different } \\
\text { group }\end{array}$ & 41,933 & 5 & 8,387 & 5,568 &, 000 \\
\hline & $\begin{array}{l}\text { Within a } \\
\text { group }\end{array}$ & 3637,686 & 2415 & 1,506 & & \\
\hline & Total & 3679,619 & 2420 & & & \\
\hline \multirow{3}{*}{$\begin{array}{l}\text { Vulnerability assessments and } \\
\text { plans }\end{array}$} & $\begin{array}{l}\text { Different } \\
\text { group }\end{array}$ & 41,377 & 5 & 8,275 & 5,745 &, 000 \\
\hline & $\begin{array}{l}\text { Within a } \\
\text { group }\end{array}$ & 3466,993 & 2407 & 1,440 & & \\
\hline & Total & 3508,370 & 2412 & & & \\
\hline
\end{tabular}

${ }^{*}$ There is a statistically significant difference between the means of dependent variables in 6 groups - Sig. $\leq 0.05$

\begin{tabular}{|c|c|c|c|c|c|}
\hline \multicolumn{6}{|c|}{ Robust Testss of Equality of Means } \\
\hline & & Statistic $^{a}$ & df1 & $\mathrm{df} 2$ & Sig. \\
\hline \multirow{2}{*}{ Level of knowledge } & Welch & 4,082 & 5 & 276,788 &, $001^{*}$ \\
\hline & Brown - Forsythe & 4,639 & 5 & 410,061 &, $000^{*}$ \\
\hline \multirow{2}{*}{ Flooding risk - 1 year } & Welch & 4,168 & 5 & 292,987 & $001^{*}$ \\
\hline & Brown - Forsythe & 3,816 & 5 & 479,677 &, $002^{*}$ \\
\hline \multirow{2}{*}{ Flooding risk - 5 years } & Welch & 1,928 & 5 & 284,149 & 090 \\
\hline & Brown - Forsythe & 1,909 & 5 & 503,565 & 091 \\
\hline \multirow{2}{*}{ Warning systems } & Welch & 8,465 & 5 & 294,780 &, $000^{*}$ \\
\hline & Brown - Forsythe & 5,375 & 5 & 556,345 &, $000^{*}$ \\
\hline
\end{tabular}


Marital Status of Citizens and Floods: Citizen Preparedness for Response to Natural Disasters

\begin{tabular}{|l|l|r|r|r|c|}
\hline \multicolumn{9}{|c|}{ Robust Testss of Equality of Means } \\
\hline \multirow{2}{*}{ Police } & Welch & Statistic & df1 & \multicolumn{1}{c|}{ df2 } & \multicolumn{1}{c|}{ Sig. } \\
\cline { 2 - 6 } & Brown - Forsythe & $\mathbf{5 , 0 3 6}$ & $\mathbf{5}$ & $\mathbf{2 9 3 , 1 7 1}$ &, $000^{*}$ \\
\hline \multirow{2}{*}{ First responders } & Welch & $\mathbf{5}$ & $\mathbf{6 0 8 , 1 1 5}$ &, $000^{*}$ \\
\cline { 2 - 6 } & Brown - Forsythe & $\mathbf{7 , 7 6 5}$ & $\mathbf{5}$ & $\mathbf{2 9 3 , 4 4 1}$ &, $000^{*}$ \\
\hline \multirow{2}{*}{ Stuff for emergency situations } & Welch & $\mathbf{5}$ & $\mathbf{6 0 1 , 9 4 7}$ &, $000^{*}$ \\
\cline { 2 - 6 } & Brown - Forsythe & 3,325 & 5 & 292,318 &, $006^{*}$ \\
\hline \multirow{2}{*}{ Escape routes } & Welch & $\mathbf{5 , 0 5 7}$ & $\mathbf{5}$ & $\mathbf{2 9 5 , 0 9 2}$ &, $007^{*}$ \\
\cline { 2 - 6 } & Brown - Forsythe & $\mathbf{4 , 2 5 5}$ & $\mathbf{5}$ & $\mathbf{6 4 4 , 0 5 8}$ &, $000^{*}$ \\
\hline \multirow{2}{*}{ Nearby shelters } & Welch & $\mathbf{5 , 4 9 0}$ & $\mathbf{5}$ & $\mathbf{2 9 2 , 0 7 2}$ &, $000^{*}$ \\
\cline { 2 - 6 } & Brown - Forsythe & $\mathbf{5 , 4 8 7}$ & $\mathbf{5}$ & $\mathbf{5 6 6 , 7 5 3}$ &, $000^{*}$ \\
\hline \multirow{2}{*}{ Vulnerability assessments and plans } & Welch & $\mathbf{6 , 3 7 0}$ & $\mathbf{5}$ & $\mathbf{2 9 3 , 8 8 2}$ &, $000^{*}$ \\
\cline { 2 - 6 } & Brown - Forsythe & $\mathbf{6 , 2 9 1}$ & $\mathbf{5}$ & $\mathbf{6 8 1 , 5 5 8}$ &, $000^{*}$ \\
\hline & a. Asymptotically F distributed. & \multicolumn{3}{l}{} \\
\hline
\end{tabular}

* There is a statistically significant difference between the means of dependent variables in 6 groups - Sig. $\leq 0.05$

The results of Chi-square test of independence $(x 2)$ showed a statistically significant relationship between marital status and the following variables on supplies and plans: supplies at home $(p=0.000<0.05, v=0.10$ - medium influence); food supply ( $p=0.019$ $<0.05, v=0.11$ - medium influence); water supply $(p=0.000<0.05, v=0.16$ - medium influence); radio-transistor ( $p=0.004<0.05, v=0.11$ - medium influence); restocking $(p=0.000<0.05, v=0.11$ - medium influence); supplies in the car $(p=0.000<0.05$, $v=0.11$ - medium influence); first aid kit at home $(p=0.000<0.05, v=0.12$ - medium influence); first aid kit in the vehicle $(p=0.000<0.05, v=0.14$ - medium influence); first aid kit - easily accessible $(p=0.000<0.05, v=0.13$ - medium influence); plan for response $(p=0.000<0.05, v=0.07$ - medium influence); Discussion on the plan $(p=0.000<0.05, v=0.09$ - medium influence); copies of documents $(p=0.000<0.05$, $v=0.12$ - medium influence); insurance $(p=0.000<0.05, v=0.17$ - medium influence) (Table 181). ${ }^{2}$ More generally speaking, in relation to marital status:

- Engaged citizens in the highest percentage: have supplies (34.3\%), food supply for a day $(23.8 \%)$, water supply for 4 days $(77.8 \%)$, annually replenish supplies $(51.4 \%)$;

- Citizens who live alone in the highest percentage (28.5\%) have supplies of food for two days; in the highest percentage (30.5\%) have supplies of water for one day;

- Married citizens in the highest percentage $(66.1 \%)$ have food supplies for 4 days, hold a first aid kit in an easily accessible place $(70.9 \%)$, discuss with family members about plans (17.7\%);

- Citizens who are in a relationship: in the highest percentage $(30.5 \%)$ have supplies of water for two days, unwritten plans in case of floods (14.2\%);

\footnotetext{
${ }^{2}$ Since the case is a table bigger than $2 \times 2$, to assess the size of the influence it is used Cramers $V$ indicator which takes into account the number of degrees of freedom. Accordingly, we used the following criteria: R-1 or $\mathrm{K}-1$ is 1 : small $=0.01$, medium $=0.30$ and large $=0.50 ; \mathrm{R}-1$ or $\mathrm{K}-1$ is 2 (three categories): Small $=0.07$, medium $=0.21$ and large $=0.35$; and R- 1 or K-1 is 3 (four categories): small $=0.06$, medium $=0.17$ and large $=$ 0.29 (Gravetter \& Wallnau, 2004).
} 
- Divorced people in the highest percentage (34.1) have a transistor radio, insurance of house/apartment against the consequences of floods $(17.2 \%)$ supplies in the car $(12.2 \%)$ have a first aid kit at home $(53.7 \%)$ replenish supplies once a month $(38.6 \%)$;

- Citizens who have lost their spouses in the highest percentage $(2.7 \%)$ have written plans in case of floods, copies of important financial and other personal documents (35.3\%).

Table 7 - Review of the results of Chi-square test of independence (X2) of marital status and possession of supplies and response plans

\begin{tabular}{|c|c|c|c|c|}
\hline Categorical variables & value & df & Asymp. Sig. (2 - sided) & Cramers v \\
\hline Supplies at home & 48,822 & 10 &, $000^{*}$ & 101 \\
\hline Food supplies & 21,395 & 10 &, $019^{*}$ &, 119 \\
\hline Water supplies & 38,757 & 10 &, $000^{*}$ & 166 \\
\hline Radio-transistor & 17,106 & 5 &, $004^{*}$ & ,117 \\
\hline Flashlight & 10,225 & 5 & 069 &, 090 \\
\hline Shovel & 6,901 & 5 & ,228 & ,074 \\
\hline Hack & 8,109 & 5 & 150 & 080 \\
\hline Hoe and spade & 7,064 & 5 & ,216 & ,074 \\
\hline Apparatus for firefighting & 6,711 & 5 & ,243 & 075 \\
\hline Restocking & 34,854 & 10 &, $000^{*}$ & ,116 \\
\hline Supplies in the car & 81,809 & 15 &, $000^{*}$ & ,110 \\
\hline First aid kit at home & 70,140 & 10 &, $000^{*}$ & ,124 \\
\hline First aid kit in the vehicle & 78,924 & 10 &, $000^{*}$ & 146 \\
\hline First aid kit- easily accessible & 74,223 & 10 &, $000^{*}$ & ,136 \\
\hline Plan for response & 44,555 & 15 &, $000^{*}$ & ,079 \\
\hline Discussion of the plan & 39,311 & 10 &, $000^{*}$ & 094 \\
\hline Copies of documents & 66,363 & 10 &, $000^{*}$ & 123 \\
\hline Insurance & 139,969 & 10 &, $000^{*}$ & 172 \\
\hline
\end{tabular}

* statistically significant correlation $-p \leq 0.05$

\section{Conclusion with recommendations}

Examining the correlation between marital status and preparedness of citizens for response to a natural disaster caused by flood in the Republic of Serbia we came to diverse conclusions. In the highest percentage:

- Citizens who are not in a relationship would engage in providing help to population in the field and the collective centers for providing help to victims of floods, they say that someone at primary/secondary school educated them about floods, have acquired information about floods from a friend, they would like to undergo some form of training for dealing with natural disasters caused by floods, they want to be educated through video - games;

- Citizens who are in relationship think about preparedness for floods due to visiting to flooded areas, they point out that someone educated them about floods in the family, have acquired information about floods at school, through the Internet, they want to be educated through the Internet, have water supplies for two days, unwritten plans in case of floods; 
- Citizens who are engaged take preventive measures to reduce tangible consequences of floods, are not yet prepared, but will start preparing next month, have recently started to prepare, have prepared for at least 6 months, would evacuated to the upper floors of the house, acquired information on floods at faculty, through an informal system of education, they have supplies, food supplies for a day, supplies of water for 4 days, they replenish their supplies once a year;

- Citizens who are married would give money to help flood victims, long-lasting rains make them to think about preparedness for floods, they know what the flood, are familiar with viruses and infections that accompany the period during and after the flood, they know where in local community elders, disabled and infants live, know safety procedures for responding during floods, would evacuated to a friend's place, say that someone at work educated them about floods, know how to handle water valve, gas valve, electricity switch, acquired information about floods in the press, have food supplies for 4 days, hold a first aid kit in an easily accessible place, discuss with family members about the plans,

- Citizens who are divorced are not yet prepared, but intend to get prepared in the next 6 months, would evacuate to neighbors' places, they know where electricity switch is, have gained information about floods from household members, they want to be educated on the radio;

- Citizens who have lost their spouses media reports make them to think about preparedness for responding to floods, do not do anything to prepare themselves, would evacuate in detention centers, they know what help is required by elders, disabled and infants, they know where water valve is, gas valve, gained information about floods from neighbors, they want to be educated through television;

On the other hand, in the smallest percentage:

- Citizens who are not in a relationship point out that someone at work educated them about floods, they know what to do after an official warning about the approach of the flood, they know where the water valve is;

- Citizens who are in a relationship would engaged in reception centers to assist victims of floods, they know what assistance is required by elders, disabled and infants, they know where electricity switch is, know how to handle water valve, gas valve, gained information on floods from neighbors, want to gain information through television;

- Citizens who are engaged think on preparedness for floods due to visiting to flooded areas, media reports, do not do anything to prepare themselves, have acquired information about floods from household members (16.1\%) want to be educated through the radio $(1.6 \%)$;

- Citizens who are divorced take preventive measures to reduce tangible consequences of floods, are not yet prepared, but will start preparing next month, have recently started preparations, they know what flood is, would evacuated to the upper floors of the house, would evacuated to reception centers, say that someone at primary/second school and within family educated them on floods, know what to do after an official warning about the approach of the flood, gained information about floods at faculty, acquired information about floods through informal system of education, in the press, they want to be educated through video - games;

- Citizens who are married acquired information on floods at school;

- Citizens who have lost their spouses would give money to help flood victims, have prepared for at least 6 months; would engage to provide help to threatened population in 
the field, think about preparedness for floods due to long-lasting rains, are not yet prepared, but intend to get prepared in the next 6 months, they are familiar with safety procedures for responding during floods, are familiar with viruses and infections accompanying the period during and after the floods, would evacuated to neighbors' places, they know where in local community elders, disabled and infants live, acquired information about floods from a friend, over the Internet, want to undergo some form of training for dealing with natural disasters caused by floods, they want to be educated over the Internet;

Furthermore, the results showed: citizens who live alone showed the highest level of preparedness of households and individual preparedness for response, while the lowest among citizens who lost their spouses; citizens who are in relationship recorded the highest level of preparedness of the local community for response, and the lowest among citizens who lost their spouses; citizens who live alone recorded the highest level of confidence in their own abilities and capabilities to cope with consequences, while the lowest among citizens who lost their spouses; citizens who are in a relationship recorded the highest level of awareness about flood risks compared to citizens who have lost their spouses who showed the lowest level; citizens who live alone recorded the highest level of knowledge about natural disasters caused by flooding, while the lowest is among citizens who are engaged; in married people, assessment of flooding risk is higher compared to citizens who are in a relationship; the best informed about threat assessments and plans are divorced people.

In terms of marital status, it should influence on citizens who are in relationship to engage in collective centers to provide assistance to flood victims. Furthermore, citizens who are in a relationship, should be educated over the Internet about location of electricity switch, how to handle valves for water and gas. Citizens who have lost their spouses should be encouraged to take measures of preparedness through visit to flooded areas and media reports. They should be inform on potential flooding risks. Citizens who are divorced should be encouraged to take preventive measures to reduce tangible consequences of floods. They need to be educated about floods and what they should do after an official warning about the approach of the flood wave. Citizens who are not in a relationship showed the highest affinity for response training. Also, it is necessary to educate them what they should do after an official warning about the approach of the flood, and where water valve is. Citizens who are married should provide water supplies for four days, transistor radio, flashlight. They need to be informed about duties of the police, first responders and the army.

\section{References}

[1] Cohen, J. W. (1988). Statistical power analysis for the behavioral sciences (2nd edn). Hillsdale, NJ: Lawrence Erlbaum Associates.

[2] Cvetković, V. (2014). Spatial and temporal distribution of floods like natural emergency situations. Paper presented at the International scientific conference Archibald Reiss days Belgrade.

[3] Cvetković, V., \& Dragicević, S. (2014). Spatial and temporal distribution of natural disasters. Journal of the Geographical Institute Jovan Cvijic, SASA, 64(3), 293-309. doi: 10.2298/ijgi1403293c

[4] Cvetković, V., Gačić, J., \& Jakovljević, V. (2015a). Geoprostorna i vremenska distribucija šumskih požara. Vojno delo, 2(2016), 108-127. 
Marital Status of Citizens and Floods: Citizen Preparedness for Response to Natural Disasters

[5] Cvetković, V., Gačić, J., \& Jakovljević, V. (2015b). Impact of climate change on the distribution of extreme temperatures as natural disasters. Vojno delo, 6/2015, 21-42.

[6] Cvetković, V., Milojković, B., \& Stojković, D. (2014). Analiza geoprostorne i vremenske distribucije zemljotresa kao prirodnih katastrofa. Vojno delo, 2/2014, 166-185.

[7] Cvetković, V. (2015a). Spremnost građana za reagovanje na prirodnu katastrofu izazvanu poplavom u Republici Srbiji. (Doktorska disertacija), Univerzitet u Beogradu, Fakultet bezbednosti.

[8] Cvetković, V. (2015b). Spremnost za reagovanje na prirodnu katastrofu - pregled literature. Bezbjednost, policija i građani, 1-2/15(XI), 165-183.

[9] Cvetković, V. (2015c). Faktori uticaja na znanje i percepciju učenika srednjih škola u Beogradu o prirodnim katastrofama izazvanim klizištima. Bezbednost, LVII(1/2015), 32-51.

[10] Cvetković, V. (2016a). Policija i prirodne katastrofe. Beograd: Zadužbina Andrejević.

[11] Cvetković, V. (2016b). Uticaj motivisanosti na spremnost građana Republike Srbije da reaguju na prirodnu katastrofu izazvanu poplavom. Vojno delo, 3/2016.

[12] Cvetković, V., \& Gačić, J. (2016). Evakuacija u prirodnim katastrofama. Beograd: Zadužbina Andrejević.

[13] Cvetković, V., Gačić, J., \& Jakovljević, V. (2015). Uticaj statusa regulisane vojne obaveze na spremnost građana za reagovanje na prirodnu katastrofu izazvanu poplavom u Republici Srbiji. Ecologica, 22(80), 584-590.Devlin, M., Waterhouse, J., Taylor, J., \& Brodie, J. (2001). Flood plumes in the Great Barrier Reef: spatial and temporal patterns in composition and distribution: Great Barrier Reef Marine Park Authority.

[14] Dragićević, S., Ristić, R., Živković, N., Kostadinov, S., Tošić, R., Novković, I., . . Radić, Z. (2013). Floods in Serbia in 2010-Case Study. The Kolubara and Pcinja River Basins. Geomorphological impacts of extreme weather: Case studies from central and eastern Europe, D. Loczy: Springer Geography.

[15] Dragićević, S., \& Filipović, D. (2009). Prirodni uslovi i nepogode u planiranju i zaštiti prostora. Beograd: Univerzitet u Beogradu, Geografski fakultet.

[16] Đarmati, Š. A., \& Aleksić, Đ. L. (2004). Razorne sile: Radnička štampa.

[17] Gillespie, D. F., Colignon, R. A., Banerjee, M. M., Murty, S. A., \& Rogge, M. (1993). Partnerships for community preparedness: US University of Colorado. Institute of Behavioral Science.

[18] Guan, Y., Zheng, F., Zhang, P., \& Qin, C. (2015). Spatial and temporal changes of meteorological disasters in China during 1950-2013. Natural Hazards, 75(3), 2607-2623.

[19] Martinez, J.-M., \& Le Toan, T. (2007). Mapping of flood dynamics and spatial distribution of vegetation in the Amazon floodplain using multitemporal SAR data. Remote sensing of Environment, 108(3), 209-223.

[20] Milojković, B., \& Mlađan, D. (2010). Adaptivno upravljanje zaštitom i spasavanjem od poplava i bujica-prilagođavanje poplavnom riziku. Bezbednost, Beograd, 52, 172-237.

[21] Momani, N. M., \& Salmi, A. (2012). Preparedness of schools in the Province of Jeddah to deal with earthquakes risks. Disaster Prevention and Management, 21(4), 463-473. doi: 10.1108/09653561211256161

[22] Prohaska, S., llić, A., Miloradović, B., \& Petković, T. (2009). Identifikacija i klasifikacija istorijskih poplava u Srbiji (Vol. 89, pp. 191-199): Serbian Geographical Society.

[23] Ronan, K. R., Alisic, E., Towers, B., Johnson, V. A., \& Johnston, D. M. (2015). Disaster Preparedness for Children and Families: a Critical Review. Current Psychiatry Reports, 17(7), 1-9.

[24] Russell, L. A., Goltz, J. D., \& Bourque, L. B. (1995). Preparedness and hazard mitigation actions before and after two earthquakes. Environment and Behavior, 27(6), 744-770.

[25] Smith, K., \& Petley, D. N. (2009). Environmental hazards. Assessing risk and reducing disaster. Londona: Routledge. 
[26] Societies, I. F. o. R. C. a. R. C. (2000). Introduction to disaster preparedness. Retrieved 30.04., 2014, from http://www.ifrc.org/Docs/pubs/disasters/resources/corner/dpmanual/all.pdf

[27] Spittal, M. J., McClure, J., Siegert, R. J., \& Walkey, F. H. (2008). Predictors of two types of earthquake preparation: survival activities and mitigation activities. Environment and Behavior.

[28] Tierney, K. J., Lindell, M. K., \& Perry, R. W. (2002). Facing the unexpected: disaster preparedness and response in the United States. Disaster Prevention and Management: $A n$ International Journal, 11(3), 222-222.

[29] Tomio, J., Sato, H., Matsuda, Y., Koga, T., \& Mizumura, H. (2014). Household and Community Disaster Preparedness in Japanese Provincial City: A Population-Based Household Survey. Advances in Anthropology, 2014.

[30] Türkeş, M., \& Sümer, U. (2004). Spatial and temporal patterns of trends and variability in diurnal temperature ranges of Turkey. Theoretical and Applied Climatology, 77(3-4), 195-227.

[31] Uscher-Pines, L., Chandra, A., \& Acosta, J. (2013). Household preparedness is not enough: the challenges and opportunities in assessing community readiness for disasters. Journal of Public Health Management and Practice, 19, S70-S76.

[32] Welsh, S. (1994). CIMAH and the Environment. Disaster Prevention and Management, 3(2), 28-43. doi: 10.1108/09653569410053923

[33] Stojanović, R. (1984). Zaštita i spasavanje ljudi i materijalnih dobara u vanrednim situacijama. Beograd: Vojno izdavački zavod.

[34] Štrbac, K., \& Terzić, K. (2007). Redefining the role of humanitarian organizations in taking care of civilians during emergencies. Vojno delo, 59(2), 64-79. 